\title{
Penerapan Model Pembelajaran Kooperatif Tipe Group Investigation (GI) untuk Meningkatkan Hasil Belajar IPA Siswa
}

\author{
I Gede Sumertha \\ SD Negeri 3 Banjar Tengah \\ e-mail: sumertha45@gmail.com
}

\begin{abstract}
Abstrak
Penelitian ini bertujuan untuk mendeskripsikan Penerapan Model Pembelajaran Kooperatif Tipe Group Investigation (GI) dalam meningkatkan hasil belajar IPA Siswa Kelas VI Semester I SD Negeri 3 Banjar Tengah Tahun Pelajaran 2017/2018. Penelitian ini termasuk jenis penelitian tindakan kelas (PTK) dengan rancangan siklustis. Subyek penelitian terdiri dari 27 orang siswa kelas VI. Objek penelitian yang disasar adalah hasil belajar siswa. Setelah data terkumpul, kemudian dianalisis dengan analisis deskriptif kuantitatif. Hasil Analisis data dalam penelitian ini menyatakan rerata hasil belajar pada prasiklus sebesar 69,07, siklus I sebesar 74,63 , dan siklus II 81,85 . Secara berurut dari pasiklus ke siklus I, prasiklus ke siklus II, dan siklus I ke siklus II terjadi peningkatan sebesar 5,56 poin, 12,78 poin dan 7,22 poin. Demikian pula terdapat peningkatan prosentase siswa yang nilai hasil belajarnya memenuhi KKM dari prasiklus, siklus I, dan siklus II, yaitu $51,85 \% ; 85,19 \%$, dan $88,89 \%$. Berdasarkan hasil analisis data dapat disimpulkan Penerapan model pembelajaran kooperatif tipe Group Investigation (GI) dapat meningkatkan hasil belajar IPA Siswa Kelas VI Semester I SD Negeri 3 Banjar Tengah pada tahun pelajaran 2017/2018.
\end{abstract}

Kata Kunci: Model Kooperatif Group Investigation (GI) dan Hasil Belajar IPA.

\begin{abstract}
This study aims to describe the Application of Cooperative Learning Model Type of Group Investigation (GI) in improving science learning outcomes of Class VI Semester I Students of SD Negeri 3 Banjar Tengah 2017/2018 Academic Year. This study included a type of classroom action research (CAR) with a cyclical design. The subjects of the study consisted of 27 class VI students. The object of research targeted is student learning outcomes. After the data is collected, then it is analyzed by quantitative descriptive analysis. The results of the analysis of the data in this study stated that the mean learning outcomes in pre-cycle were 69.07, the first cycle was 74.63, and the second cycle was 81.85 . Sequentially from post-cycle to cycle I, pre-cycle to cycle II, and cycle I to cycle II there was an increase of 5.56 points, 12.78 points, and 7.22 points. Likewise, there is an increase in the percentage of students whose learning outcomes meet the KKM from pre-cycle, cycle I, and cycle II, which is $51.85 \%$; $85.19 \%$, and $88.89 \%$. Based on the results of data analysis it can be concluded that the application of the cooperative learning model type Group Investigation (Gl) can improve the science learning outcomes of Class VI Semester I Students at SD Negeri 3 Banjar Tengah in the 2017/2018 school year.
\end{abstract}

Keywords: Cooperative Group Investigation (Gl) Model and Science Learning Outcomes. 


\section{Pendahuluan}

Pendidikan merupakan suatu proses yang diperlukan untuk mendapatkan keseimbangan dan kesempurnaan dalam perkembangan individu maupun masyarakat. Penekanan pendidikan dibanding dengan pengajaran terletak pada pembentukan kesadaran dan kepribadian individu atau masyarakat di samping transfer ilmu dan keahlian. Dengan proses semacam ini suatu bangsa atau negara dapat mewariskan nilai-nilai keagamaan, kebudayaan, pemikiran dan keahlian kepada generasi berikutnya, sehingga mereka betul-betul siap menyongsong masa depan kehidupan bangsa dan negara yang lebih cerah (Nurkholis, 2013).

Secara tegas Permendiknas No. 22 tahun 2006 menyebutkan bahwa Pendidikan Nasional yang berdasarkan Pancasila dan Undang-Undang Dasar Negara Republik Indonesia Tahun 1945 berfungsi mengembangkan kemampuan dan membentuk watak serta peradaban bangsa yang bermartabat dalam rangka mencerdaskan kehidupan bangsa, bertujuan untuk mengembangkan potensi peserta didik agar menjadi manusia yang beriman dan bertakwa kepada Tuhan Yang Maha Esa, berakhlak mulia, sehat, berilmu, cakap, kreatif, mandiri, dan menjadi warga negara yang demokratis serta bertanggung jawab.

Sebagai ujung tombak pembangunan, guru dalam mengemban tugasnya selalu berpedoman dan mengacu pada tujuan pendidikan nasional seperti yang telah dicantumkan di atas. Pendidikan diarahkan untuk meningkatkan kualitas manusia Indonesia seutuhnya melalui olahhati, olahpikir, olahrasa dan olahraga agar memiliki daya saing dalam menghadapi tantangan global. Untuk menentukan berhasil atau gagalnya siswa menempuh pendidikan dalam suatu lembaga, secara umum digunakan tolok ukur hasil belajar (Tirka,1994:12). Hal ini disebabkan karena hasil belajar merupakan salah satu indikasi tentang hasil pendidikan. Guru melakukan penilaian untuk mengukur tingkat pencapaian kompetensi peserta didik, serta digunakan sebagai bahan penyusunan laporan kemajuan hasil belajar, dan memperbaiki proses pembelajaran. Hasil belajar seorang individu merupakan interaksi antara berbagai faktor yang mempengaruhinya, yang secara umum dikelompokkan menjadi dua faktor besar yaitu faktor dalam dan faktor luar. Yang termasuk faktor dalam antara lain faktor kesehatan jasmani, bakat, minat, motivasi, intelegensi dan sebagainya. Sedangkan yang termasuk faktor luar meliputi kelengkapan sarana prasarana, waktu, kondisi belajar, sumber belajar, kondisi lingkungan, pendekatan guru yang digunakan dalam proses pembelajaran dan sebagainya.

Pendidikan pada Sekolah Dasar bertujuan memberikan bekal kepada siswa untuk hidup bermasyarakat dan dapat melanjutkan pendidikan ke jenjang yang lebih tinggi. Menurut Permendiknas No. 23 tahun 2006, Standar Kompetensi Lulusan Satuan Pendidikan (SKLSP) dikembangkan berdasarkan tujuan setiap satuan pendidikan. Untuk pendidikan dasar bertujuan untuk meletakkan dasar kecerdasan, pengetahuan, kepribadian, akhlak mulia, serta keterampilan untuk hidup mandiri dan mengikuti pendidikan lebih lanjut. Standar Kompetensi Lulusan Satuan Pendidikan (SKLSP) yang termasuk dalam IPA SD/MI antara lain: a. Menggunakan informasi tentang lingkungan sekitar secara logis, kritis, dan kreatif. $b$. Menunjukkan kemampuan berpikir logis, kritis, dan kreatif dengan bimbingan guru/pendidikan c. Menunjukkan rasa keingintahuan yang tinggi dan menyadari potensinya. d. Menunjukkan kemampuan memecahkan masalah sederhana dalam kehidupan sehari - hari. e. Menunjukkan kemampuan mengenali gejala alam dan sosial di lingkungan sekitar. f. Menunjukkan kecintaan dan kepedulian terhadap lingkungan.

Menurut Permendiknas No. 22 tahun 2006, IPA berhubungan dengan cara mencari tahu tentang alam secara sistematis, sehingga IPA bukan hanya penguasaan kumpulan pengetahuan yang berupa fakta - fakta, konsep - konsep, atau prinsip - prinsip saja, tetapi juga merupakan suatu proses penemuan. Pendidikan IPA diharapkan menjadi wahana siswa untuk mempelajari diri sendiri dan alam sekitar serta prospek pengembangan lebih lanjut dalam menerapkannya di dalam kehidupan sehari-hari.

Tercapainya tujuan pendidikan IPA ditentukan apabila didukung oleh iklim pembelajaran yang kondusif. Iklim pembelajaran yang dikembangkan oleh guru mempunyai pengaruh yang sangat besar terhadap keberhasilan dan kegairahan belajar siswa (Azis Wahab, 2011). Ketepatan guru dalam memilih dan menggunakan model pembelajaran sangat mempengaruhi kualitas dan keberhasilan pembelajaran. Siswa akan dapat belajar dan mencapai hasil yang baik, apabila didukung oleh kondisi lingkungan yang memadai serta model yang digunakan guru dalam pembelajaran. Dalam belajar, siswa diarahkan berinteraksi dengan semua sumber belajar termasuk guru dan siswa yang lainnya. Seorang guru hendaknya mampu merancang pembelajaran untuk memberikan kesempatan kepada siswa agar terjadi multi interaksi yaitu siswa berinteraksi dengan komponen-komponen pembelajaran yang lain. 
Menurut Dimyati dan Mudjiono (1999), hasil belajar merupakan hal yang dapat dipandang dari dua sisi yaitu sisi siswa dan dari sisi guru. Dari sisi siswa, hasil belajar merupakan tingkat perkembangan mental yang lebih baik bila dibandingkan pada saat sebelum belajar. Howard Kingsley (Nana Sudjana, 2005: 85) membagi 3 macam hasil belajar: 1) Keterampilan dan kebiasaan; 2) Pengetahuan dan pengertian; dan 3) Sikap dan cita-cita. Pendapat dari Horward Kingsley ini menunjukkan hasil perubahan dari semua proses belajar. Hasil belajar ini akan melekat terus pada diri siswa karena sudah menjadi bagian dalam kehidupan siswa tersebut.

Berdasarkan pengertian di atas maka dapat disintesiskan bahwa hasil belajar adalah suatu penilaian akhir dari proses dan pengenalan yang telah dilakukan berulang-ulang. Serta akan tersimpan dalam jangka waktu lama atau bahkan tidak akan hilang selama-lamanya karena hasil belajar turut serta dalam membentuk pribadi individu yang selalu ingin mencapai hasil yang lebih baik lagi sehingga akan mengubah cara berpikir serta menghasilkan perilaku kerja yang lebih baik (Sulastri, 2014).

Pemilihan model pembelajaran yang tepat sangatlah penting agar tujuan pembelajaran dapat tercapai. Meskipun tujuan pembelajaran dirumuskan dengan baik, materi yang dipilih sudah tepat, jika model pembelajaran yang dipergunakan kurang memadai mungkin tujuan yang diharapkan tidak tercapai dengan baik. Jadi, model pembelajaran merupakan salah satu komponen pembelajaran yang penting dan sangat menentukan dalam keberhasilan proses pembelajaran (Hartoto, 2016).

Penentuan model pembelajaran yang sesuai dengan tujuan kurikulum dan keterampilan dasar harus dimiliki oleh seorang guru (Kosasih,1992:28). Dalam penyelenggaraan pembelajaran seorang pendidik harus bisa memilih model mengajar yang sesuai untuk suatu materi tertentu dan menggunakan interaksi belajar mengajar yang berdaya guna untuk mencapai tujuan pembelajaran. Oleh karena itu dalam mengajar, pendidik harus mampu memilih model mengajar yang cocok untuk masing-masing materi pembelajaran, yang harus disesuaikan dengan tujuan pembelajaran. Dengan memilih model pembelajaran yang tepat untuk suatu materi, akan membawa hasil yang baik dan suasana menyenangkan sehingga siswa mudah memahami materi yang dipelajari.

Kenyataan umum menggambarkan bahwa pendidikan IPA sering kali dikemas dengan nuansa lama yang konvensional. Pembelajaran IPA belum diarahkan pada aliran pembelajaran kekinian, yang mana menuntut nuansa pembelajaran aktif, inovatif, kreatif, efektif, dan menyenangkan. Hal ini tidak terkecuali terjadi pada SD Negeri 3 Banjar Tengah. Dari pengalaman mengajar IPA dan berdasarkan hasil observasi prasiklus yang telah dilakukan oleh peneliti, ternyata masih saja hasil belajar IPA kurang maksimal. Hasil evaluasi prasiklus menunjukan bahwa dari 27 siswa yang dievaluasi, hanya 14 siswa $(51,85 \%)$ yang memenuhi KKM (70), dan $13(48,15 \%)$ belum memenuhi KKM. Peneliti menganalisa bahwa penyebab hasil belajar yang kurang maksimal tersebut antara lain, (1) pemilihan dan penerapan model pembelajaran inovatif kurang tepat dan mantap, (2) pengetahuan awal siswa yang belum terakomodasi dengan baik dalam pembelajaran, (3) guru belum maksimal memanfaatkan potensi lingkungan sebagai media dan sumber belajar, (4) sistem penilaian digunakan kurang sesuai dengan tujuan esensial pembelajaran IPA di sekolah dasar, (5) Peneliti beranggapan bahwa, dalam menerapkan cooperative learning tiap kali menyuruh siswa bekerja di dalam kelompok-kelompok kecil. Tetapi belum memperhatikan adanya aktivitas kelas yang terstruktur, sehingga peran setiap anggota kelompok belum terlihat.

Model pembelajaran kooperatif tipe group investigation (GI) adalah salah satu model pembelajaran yang mendekati standar proses yang diamanatkan dalam peraturan pemerintah dan sesuai dengan paham konstruktivisme yang memandang bahwa mengajar bukanlah memindahkan pengetahuan dari guru ke siswa, melainkan suatu kegiatan yang memungkinkan siswa untuk membangun sendiri pengetahuannya. Sehingga setelah mencermati kelebihan/keunggulan model pembelajaran kooperatif tipe group investigation (Gl) maka sebagai solusi terhadap masalah yang dihadapi peneliti, maka akan dilakukan peneitian yang menerapkan model pembelajaran kooperatif tipe Group Investigation (GI) dengan judul "Penerapan Model Pembelajaran Kooperatif tipe Group Investigation (GI) untuk Meningkatkan Hasil Belajar IPA Siswa Kelas VI Semester I SD Negeri 3 Banjar Tengah Tahun Pelajaran 2017/2018".

Sutama (2007) menyatakan bahwa model pembelajaran group investigation merupakan pembelajaran berbasis kelompok yang memberikan peluang kepada siswa untuk berdiskusi, berfikir kritis, dan dapat bertanggung jawab dalam pembelajaran tersebut. Senada dengan apa yang dikemukakan oleh Santyasa (2009) dalam Wahyuningsih, dkk. (2012), bahwa 
pembelajaran investigasi kelompok mengarahkan aktivitas kelas yang berpusat pada siswa dan menyediakan peluang kepada guru menggunakan lebih banyak waktu untuk melakukan diagnosa dan koreksi terhadap masalah-masalah yang dialami oleh siswa (Artini, 2016).

Penggunaan model pembelajaran group investigation dapat membuat siswa aktif dan mengembangkan pengetahuan mereka. Cooperative learning tipe group investigation memungkinkan siswa untuk saling bertukar pendapat, saling berinteraksi, bertukar pikiran mengenai materi yang mereka pelajari. Siswa dibagi berkelompok-kelompok yang anggotanya empat sampai lima orang secara heterogen, Guru memberikan suatu masalah kemudian guru membagikan subtopik yang berbeda pada setiap kelompok untuk didiskusikan dan dianalisis, selanjutnya mereka mempresentasikan hasil diskusi mereka (Wahidin, 2018).

Berdasarkan latar belakang masalah di atas, permasalahan dalam penelitian tindakan kelas ini dapat dirumuskan sebagai berikut: Apakah Penerapan Model Pembelajaran Kooperatif tipe Group Investigation (GI) dapat Meningkatkan Hasil Belajar IPA Siswa Kelas VI Semester I SD Negeri 3 Banjar Tengah Tahun Pelajaran 2017/2018?

\section{Metode}

Penelitian tindakan adalah suatu bentuk penelitian refleleksi-diri yang dilakukan oleh para partisipan dalam situasi-situasi sosial (termasuk pendidikan) untuk memperbaiki praktek yang dilakukan sendiri. Dengan demikian akan diperoleh pemahaman mengenai praktek tersebut dan situasi di mana praktek tersebut dilaksanakan. Terdapat dua esensi penelitian tindakan yaitu perbaikan dan keterlibatan. Hal ini mengarahkan tujuan penelitian tindakan ke dalam tiga area yaitu: (1) Untuk memperbaiki praktek; (2) Untuk pengembangan profesional dalam arti meningkatkan pemahaman/kemampuan para praktisi terhadap praktek yang dilaksanakannya; (3) Untuk memperbaiki keadaan atau situasi di mana praktek tersebut dilaksanakan.

Dari siklus dasar yang ada, penulis menetapkan untuk menggunakan model Penelitian yang diberikan oleh Direktorat Jendral Peningkatan Mutu Pendidik dan Tenaga Kependidikan (2009) yang langkah-langkahnya dapat dilihat pada gambar berikut :

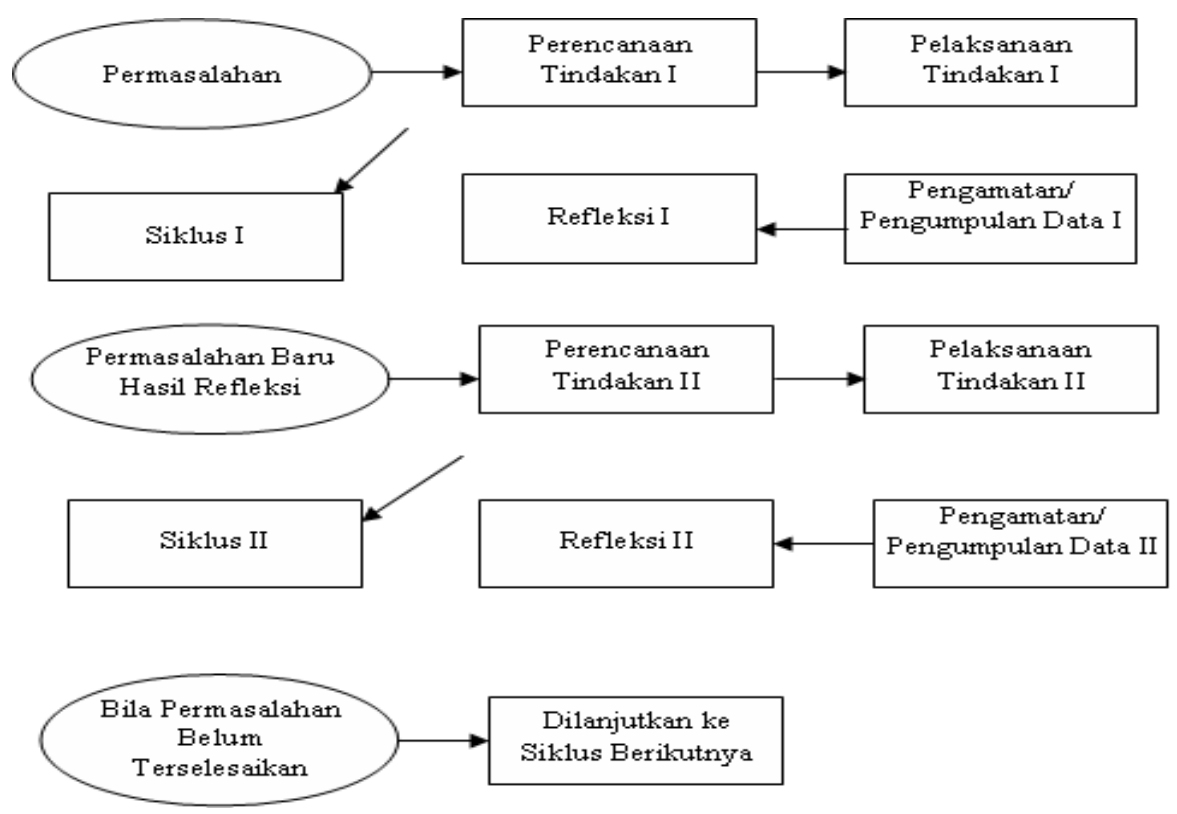

Gambar 1. Langkah-langkah Siklus dasar

Berdasarkan data hasil belajar yang dilakasanakan pada pra siklus maka siswa dikelompokan sebagai berikut: a) 14 orang siswa sudah memenuhi KKM, b) 13 siswa hasil belajarnya belum memenuhi KKM. Besaran KKM adalah 70. Oleh karena itu maka pemberian tindakan akan akan diberikan pada seluruh siswa kelas VI yaitu 27 siswa sebagai subyek penelitian. 
Objek penelitian merupakan hasil atau output yang diperlihatkan oleh subjek penelitian sebagai akibat dari penerapan tindakan yang diimplementasikan. Dengan demikian, objek dari penelitian ini adalah hasil belajar siswa yang diukur pada prasiklus, siklus I, dan siklus II.

Tahap pengamatan dan pengukuran berjalan bersamaan dengan tahap pelaksanaan. Pengamatan dilakukan pada waktu tindakan sedang berjalan. Pada tahap ini dilakukan pengamatan dan pencatatan semua hal yang diperlukan dan yang terjadi selama pelaksanaan tindakan berlangsung.

Untuk mengukur keberhasilan pemberian tindakan, dalam penelitian ini ditetapkan indicator keberhasilan yang dijadikan sebagai acun apakah pemberian tindakan sudah berhasil atau belum. Adapaun indikator keberhasilannya adalah: Pemberian tindakan dianggap berhasil jika minimal $80 \%$ siswa mencapai hasil belajar sesuai KKM (70), serta rerata hasil belajar minimal 80,00 .

Untuk menguji hipotesis tindakan yang sudah dirumuskan digunakan analisis statistik deskriptif kuantitatif. Statistik deskriptif kuantitatif adalah suatu jenis statistik yang bertujuan untuk menjelaskan perbandingkan rerata skor bidang studi IPA siswa dari prasiklus ke siklus I, dari prasiklus ke siklus II, dan dari siklus I ke siklus II, sehingga dapat diinferensikan makna tertentu. Dalam hal ini dari perbandingan yang dimaksudkan dapat diketahui berapa poin peningkatan hasil belajar IPA siswa.

\section{Hasil dan Pembahasan}

\section{Pada Pra Siklus}

Pembelajaran pada prasiklus dilaksanakan dengan menggunakan pedoman berupa Rencana Pelaksanaan Pembelajaran (RPP) yang disusun peneliti. Mengacu pada jadwal pelajaran dan jadwal penelitian yang telah dibuat, maka kegiatan prasiklus dilaksanakan sebanyak 3 kali pertemuan. Untuk mengomunikasikan materi pembelajaran diterapkan metode kooperatif yang tidak terstruktur.

Untuk mengukur hasil belajar IPA siswa digunakan instrument berupa tes hasil belajar. Selanjutnya data hasil belajar siswa dibuatkan deskripsinya. Deskripsi data yang dimaksudkan meliputi: rerata $=63,25$; standar deviasi $=13,45$; median $=70$; modus 60 ; banyak kelas $=6$; rentangan $=55$; panjang interval $=9,17$ berikut:

Mengenai distribusi frekuensi hasil belajar IPA pada prasiklus dapat disajikan pada tabel

Tabel 1. distribusi frekuensi hasil belajar IPA pada prasiklus.

\begin{tabular}{ccccccc}
\hline $\begin{array}{c}\text { Nomor } \\
\text { Urut }\end{array}$ & \multicolumn{2}{c}{ Interval } & Nilai Tengah & $\begin{array}{c}\text { Frekwensi } \\
\text { Absolut }\end{array}$ & frekwensi Relatif \\
\hline 1 & 40,00 & - & 49,16 & 44,58 & 1 & 3,70 \\
2 & 49,17 & - & 58,32 & 53,75 & 3 & 11,11 \\
3 & 58,33 & - & 67,49 & 62,91 & 9 & 33,33 \\
4 & 67,50 & - & 76,66 & 72,08 & 8 & 29,63 \\
5 & 76,67 & - & 85,82 & 81,25 & 3 & 11,11 \\
6 & 85,83 & - & 95,00 & 90,42 & 3 & 11,11 \\
& Jumlah & & & 27 & 100,00 \\
\hline
\end{tabular}

Dapat dijelaskan bahwa $14,81 \%$ siswa hasil belajarnya berada di bawah rerata; $33,33 \%$ berada pada sekitar rerata, sementara yang sudah memenuhi rerata hanya $51,85 \%$. Bila hasil analisis data dibandingkan dengan kriteria ketuntasan minimum (KKM) yang besarnya 70,00 dapat dikemukakan hal-hal sebagai berikut. Sebanyak 14 siswa $(51,85 \%)$ memperoleh skor memenuhi KKM dan sebanyak $13(48,15 \%)$ siswa memperoleh skor di bawah KKM. Adapun kategori skor hasil belajar pada pra siklus dapat dikatakan bahwa sebanyak $13(48,15 \%)$ termasuk kategori sedang (B3), dan sebanyak $14(51,85 \%)$ termasuk kategori tinggi (B1)

\section{Pada Siklus I}

Pemberian tindakan pada siklus I mengikuti desain penelitian tindakan kelas (PTK), yaitu meliputi 4 tahapan: perencanaan, tahap pelaksanaan tindakan, tahap observasi dan pengukuran, dan tahap refleksi. 
Data hasil belajar siswa selanjutnya dianalisis secara deskriptif kualitatif, adapun deskripsi data meliputi: rerata $=74,63$; standar deviasi $=9,92 ;$ median $=75$; modus $=70$; banyak kelas $=6$; rentangan $=40 ;$ panjang interval $=6,67$ berikut:

Adapun data distribusi frekuensi hasil belajar IPA pada Siklus I dapat disajikan pada tabel

Tabel 2. distribusi frekuensi hasil belajar IPA pada Siklus I

\begin{tabular}{ccccccc}
\hline Nomor Urut & \multicolumn{2}{c}{ Interval } & $\begin{array}{c}\text { Nilai } \\
\text { Tengah }\end{array}$ & $\begin{array}{c}\text { Frekwensi } \\
\text { Absolut }\end{array}$ & $\begin{array}{c}\text { frekwensi } \\
\text { Relatif }\end{array}$ \\
\hline 1 & 50,00 & - & 56,66 & 53,33 & 2 & 7,41 \\
2 & 56,67 & - & 63,32 & 60,00 & 1 & 3,70 \\
3 & 63,33 & - & 69,99 & 66,66 & 1 & 3,70 \\
4 & 70,00 & - & 76,66 & 73,33 & 11 & 40,74 \\
5 & 76,67 & - & 83,33 & 80,00 & 7 & 25,93 \\
6 & 83,34 & & 90,00 & 86,67 & 5 & 18,52 \\
& Jumlah & & & 27,00 & 100,00 \\
\hline
\end{tabular}

Hasil analisis data memperlihatkan bahwa $14,81 \%$ siswa memperoleh skor di bawah rata-rata, $40,74 \%$ pada sekitar rerata dan sebanyak $44,44 \%$ memperoleh skor di atas rata-rata.

Bila data di atas diperbandingkan dengan KKM (70), maka dapat dideskripsikan hal hal sebagai berikut: sebanyak 23 orang siswa $(85,19 \%)$ sudah memenuhi KKM, sebanyak 4 orang $(14,81 \%)$ belum memenuhi KKM. Demikian pula jika dikonversikan dengan acuan penilaian kriteria (criterion referenced) dapat dijelaskan bahwa 23 siswa $(85,19 \%)$ berada pada kategori tinggi, 4 siswa (14,82\%) kategori sedang, dan $0 \%$ yang berada pada kategori rendah, sedangkan rerata hasil belajar berada pada kategori sedang

\section{Pada Siklus II}

Pemberian tindakan pada siklus II mengikuti desain penelitian seperti yang telah dilaksanakan pada siklus I, yaitu meliputi 4 tahapan: tahap perencanaan, tahap pelaksanaan tindakan, tahap observasi dan pengukuran, dan tahap refleksi.

Data hasil belajar siswa selanjutnya dianalisis secara deskriptif kualitatif, adapun deskripsi data meliputi: rerata $=81,85$; standar deviasi $=11,03$; median $=85$; modus $=90$; banyak kelas $=6$; rentangan 40 ; panjang interval 6,67

Mengenai data distribusi frekuensi hasil belajar IPA pada Siklus II dapat disajikan pada tabel berikut:

Tabel 3. distribusi frekuensi hasil belajar IPA pada Siklus II

\begin{tabular}{ccccccc}
\hline $\begin{array}{c}\text { Nomor } \\
\text { Urut }\end{array}$ & \multicolumn{2}{c}{ Interval } & $\begin{array}{c}\text { Nilai } \\
\text { Tengah }\end{array}$ & $\begin{array}{c}\text { Frekwensi } \\
\text { Absolut }\end{array}$ & $\begin{array}{c}\text { frekwensi } \\
\text { Relatif }\end{array}$ \\
\hline 1 & 60,00 & - & 66,66 & 63,33 & 3 & 11,11 \\
2 & 66,67 & - & 73,32 & 70,00 & 4 & 14,81 \\
3 & 73,33 & - & 79,99 & 76,66 & 3 & 11,11 \\
4 & 80,00 & - & 86,66 & 83,33 & 5 & 18,52 \\
5 & 86,67 & - & 93,33 & 90,00 & 8 & 29,63 \\
6 & 93,34 & 100,00 & 96,67 & 4 & 14,81 \\
& Jumlah & & & 27,00 & 100,00 \\
\hline
\end{tabular}

Hasil analisa data memperlihatkan bahwa sebanyak $44,44 \%$ siswa memperoleh skor di bawah rata-rata, dan sebanyak $18,52 \%$ siswa memperoleh skor sekitar rerata, dan $37,04 \%$ siswa berada di atas rata-rata. Bila data di atas diperbandingkan dengan KKM (70) maka mata pelajaran IPA, maka dapat dideskripsikan hal - hal sebagai berikut: sebanyak 24 orang siswa $(88,89 \%)$ sudah memenuhi KKM, sebanyak 3 orang $(11,11 \%)$ belum memenuhi KKM. Demikian pula jika dikonversikan dengan acuan penilaian kriteria (criterion referenced) dapat dijelaskan bahwa 24 siswa $(88,89 \%)$ berada pada kategori tinggi, 3 siswa $(11,11 \%)$ kategori sedang, dan $0.00 \%$ yang berada pada kategori rendah, sedangkan rerata hasil belajar berada pada kategori tinggi.

Analisis Data Analisis data hasil penelitian dilakukan dengan memperbandingkan rerata skor pada setiap siklusnya, sehingga analisa datanya adalah secara deskriptif kualitatif. Dari ke tiga perbandingan rerata hasil belajar yakni: dari pra siklus ke siklus I, dari pra siklus ke siklus II, 
dan siklus I ke siklus II maka terjadi peningkatan rerata secara berturut turut sebesar 5,56 poin, 12,78 poin dan 7,22 poin. Oleh karena ketiga perbandingan menyatakan peningkatan poin, maka hipotesis tindakan diterima. Hal ini berarti Penerapan model pembelajaran kooperatif tipe Group Investigation (GI) dapat meningkatkan hasil belajar IPA Siswa Kelas VI Semester I SD Negeri 3 Banjar Tengah pada tahun pelajaran 2017/2018.

Temuan dalam penelitian ini menyatakan Penerapan model pembelajaran kooperatif tipe Group Investigation (GI) dapat meningkatkan hasil belajar IPA Siswa. Hal ini didukung dengan adanya peningkatan rerata hasil belajar pada setiap siklus, yaitu dari pra siklus ke siklus I, dari pra siklus ke siklus II, dan siklus I ke siklus II maka terjadi peningkatan rerata secara berturut turut sebesar 5,56 poin, 12,78 poin dan 7,22 .

Temuan dalam penelitian ini sejalan dengan temuan pada beberapa penelitian sebelumnya. Implementasi model pembelajaran kooperatif tipe Group Investigation (GI) ternyata mampu menigkatkan hasil belajar siswa pada setiap siklusnya, hal ini sesuai dengan pendapat Redhana \& Widana, yang menyatakan pembelajaran kooperatif memberikan dampak positif antara lain: (1) membangun komunitas kerja sama, (2) meningkatkan motivasi belajar, (3) mengurangi individualisasi dan persaingan, (4) meningkatkan partisipasi siswa dalam pembelajaran, dan (5) meningkatkan pemahaman dan hasil belajar siswa. Demikian pula, menurut Felder (dalam Redhana, 2003) keuntungan dari pembelajaran kooperatif antara lain: 1) meningkatkan motivasi dan hasil belajar siswa, 2) meningkatkan keterlibatan siswa dalam debat secara aktif tentang masalah terbuka yang dihadapi (open ended problem), 3) kerjasama kelompok dapat berlangsung secara efektif dan dapat membantu siswa menguasi konsep konsep yang dipelajari, 4) meningkatkan ketertarikan siswa terhadap materi subyek, 5) meningkatkan kekompakkan dalam kerja team, 6) meningkatkan daya ingat siswa, 7) meningkatkan sikap positif siswa terhadap materi subyek dan lebih yakin dengan studi lebih lanjut, dan 8) meningkatkan kemampuan siswa dalam memformulasikan masalah dan dalam memecahkan masalah.

Pelaksanaan pembelajaran melalui model group investigation (GI) melibatkan siswa secara langsung dalam perencanaan, baik dalam memilih topik maupun prosedur atau langkahlangkah yang diikuti siswa dalam proses investigasi mereka. Dalam pembelajaran dengan pendekatan group investigation yang bersifat humanis, ada beberapa konsep penting yang mesti diperhatikan (Jacobs, dkk., 2004) yaitu (1) menghindarkan evaluasi menggunakan tes, (2) learning by doing, (3) membangun motivasi instrinsik, (4) mengutamakan pilihan siswa, (5) memperlakukan siswa sebagai orang yang bertanggung jawab, (6) pertanyaan-pertanyaan terbuka, (7) mendorong rasa saling menghormati dan saling membantu, dan (8) membangun konsep diri yang positif.

\section{Simpulan dan Saran}

Berdasarkan hasil analisis data dan pembahasan yang telah disajikan dalam Bab IV, maka dapat ditarik simpulan sebagai berikut: Penerapan model pembelajaran kooperatif tipe Group Investigation (GI) dapat meningkatkan hasil belajar IPA Siswa Kelas VI Semester I SD Negeri 3 Banjar Tengah pada tahun pelajaran 2017/2018. Hal ini dibuktikan dengan adanya peningkatatan rerata hasil belajar pada prasiklus sebesar 69,07; siklus I sebesar 74,63; dan siklus II 81,85 . Secara berurut dari pasiklus ke siklus I, prasiklus ke siklus II, dan siklus I ke siklus II terjadi peningkatan sebesar 5,56 poin, 12,78 poin dan 7,22 poin. Demikian pula terdapat peningkatan prosentase siswa yang nilai hasil belajarnya memenuhi KKM dari prasiklus, siklus I, dan siklus II, yaitu $51,85 \% ; 85,19 \%$, dan $88,89 \%$.

\section{Daftar Pustaka}

Artini (2016). Penerapan Model Pembelajaran Kooperatif Tipe Group Investigation Untuk Meningkatkan Aktivitas Dan Hasil Belajar Ipa Pada Siswa Kelas Vi Sd Inpres 1 Tondo . E-Jurnal Mitra Sains, Volume 4 Nomor 1, Januari 2016

Hartoto, Tri (2016). Model Pembelajaran Kooperatif Tipe Group Investigation (Gi) Meningkatkan Aktivitas Dan Hasil Belajar Sejarah. Jurnal Historia Volume 4, Nomor 2, Tahun 2016, Issn 2337-4713 (E-Issn 2442-8728)

Kosasih, H. Djahiri. 1992. Dasar-Dasar Metodologi Pengajaran. Bandung: Lab Pengajaran PMP IKIP Bandung. 
Mendiknas. 2006. Permendiknas RI Nomor 22. Jakarta: Mendiknas.

Mendiknas. 2006. Permendiknas RI Nomor 23. Jakarta: Mendiknas.

Mendiknas. 2007. Permendiknas RI Nomor 41. Jakarta: Mendiknas.

Nurkholis (2013). Pendidikan Dalam Upaya Memajukan Teknologi . Jurnal Kependidikan, Vol. 1 No. 1 Nopember 2013

Redhana, I W. 2003. Meningkatkan keterampilan pemahaman konsep dan pemahaman mahasiswa Jurusan Pendidikan Kimia Fakultas Pendidikan MIPA IKIP Negeri Singaraja melalui metode pembelajaran kooperatif dan open-ended laboratory praktikum biokimia I pada tahun akademik 2002/2003. Laporan Penelitian (tidak diterbitkan). IKIP Negeri Singaraja.

Sulastri (2014). Meningkatkan Hasil Belajar Siswa Melalui Strategi Pembelajaran Berbasis Masalah Pada Mata Pelajaran IPS di Kelas V SDN 2 Limbo Makmur Kecamatan Bumi Raya . Jurnal Kreatif Tadulako Online Vol. 3 No. 1 ISSN 2354-614X

Tirka, I W. 1994. Determinasi Factor Kejelasan Guru Efektifitas Interaksi, dan Lingkungan Belajar Terhadap Self Esteem dan Prestasi Akademis Siswa SMP Negeri Di Bali. Hasil Penelitian (Tidak Dipublikasikan). Singaraja: STKIP Singaraja.

Wahab, Abdul Aziz dan Sapriya. 2011. Teori \& Landasan Pendidikan Kewarganegaraan. Bandung: Alfabeta.

Wahidin (2018). Upaya Meningkatkan Prestasi Belajar IPA melalui Model Pembelajaran Kooperatif Tipe Group Investigation pada Siswa Kelas V MIN Semanu Gunungkidul . Jurnal Pendidikan Madrasah, Volume 3, Nomor 1, Mei 2018 P-ISSN: 2527-4287 - EISSN: 2527-6794 